Saudi Journal of Medical and Pharmaceutical Sciences

Abbreviated Key Title: Saudi J Med Pharm Sci

ISSN 2413-4929 (Print) |ISSN 2413-4910 (Online)

Scholars Middle East Publishers, Dubai, United Arab Emirates

Journal homepage: https://saudijournals.com

Original Research Article

\title{
Structural Elucidation of Two Unique Antimicrobial Cassane - Type Tricyclic Diterpenes from the Root of Calliandra portoricensis (JACQ)-BENTH
} (Fabaceae)

Oguegbulu NE*, Abo AK and Afieroho OE

All of Department of Pharmacognosy and Phytotherapy Faculty of Pharmaceutical Sciences, University of Port Harcourt, Rivers State, Nigeria

\begin{tabular}{ll}
\hline DOI: $10.36348 /$ sjmps.2020.v06i12.001 & | Received: 20.11 .2020 | Accepted: $03.12 .2020 \mid$ Published: 10.12 .2020 \\
*Corresponding author: Oguegbulu NE &
\end{tabular}

Abstract

The burden of infectious diseases by bacteria and fungi had constituted a great concern to the entire human population. Calliandra portoricensis (Fabaceae) had been widely used over the years in ethnomedicine for the; treatment of various ailments such as swollen gum, tooth and throat inflammation often associated with microbial infections. At present, no active antimicrobial compound has been reported from this specie. The aim of this research was to identify, isolate and characterize the antimicrobial compounds from the root of $C$. portoricensis. The pulverized root sample $(0.8 \mathrm{Kg})$ was extracted by successive cold maceration respectively for $72 \mathrm{hr}$.. The most bioactive ethyl acetate extract (4.61 gm) was subjected to chromatographic column fractionation (Silica Gel G, 200-400 mesh-stationary phase). Gradient mixtures of n-hexane: ethyl acetate: methanol $(4: 0: 0 ; 3: 1: 0 ; 2: 2: 0 ; 1: 3: 0 ; 0: 1: 0 ; 0: 3: 1 ; 0: 2: 2 ; 0: 1: 3 ; 0: 0: 4 ;-$ v/v/v) were used for elution. Agar well diffusion method was adopted for the bioassays susceptibility tests and MIC determinations. Clinically viable human pathogens for the tests were; Staphylococcus aureus, Escherichia coli, Bacillus subtilis, Klebsiella pneumonia, Streptococus fecalis, Candida albicans and Aspergillus niger. Two major fractions $\left(\mathrm{F}_{\mathrm{A}}\right.$ and $\left.\mathrm{F}_{\mathrm{B}}\right)$ active against the test organisms were pooled The more active fraction $\mathrm{F}_{\mathrm{B}}$ on further purification by preparative TLC (Silica Gel G, 0.5 $\mathrm{mm}$ thickness), yielded bioactive pure commands $C_{1}(9 \mathrm{mg})$ and $\mathrm{C}_{2}(8 \mathrm{mg})$. Both compounds exhibited MIC values of $125.00 \pm 0.70 \mu \mathrm{g}$ per $\mathrm{ml}$ against Candida albicans and Aspergillus niger These activities were found to be quite significant with respect to the reference controls (Ciprofloxacin and fluconazole) at $\mathrm{P} \leq 0.05$. Characterization of $\mathrm{C}_{1}$ and $\mathrm{C}_{2}$ by spectroscopic analysis (UV, MS, FT - IR and NMR), identified two novel compounds as Cassane - type tricyclic diterpenoids. $\mathrm{C}_{1}$ (Molecular Mass: 324, $\mathrm{C}_{20} \mathrm{H}_{36} \mathrm{O}_{3}$ ) is (5,10- 8,9- 12,13)-seco 4,4,10 - trimethyl, 14 - hydroxymethyl, 16 - keto, 13(15) - ene - cassane furanoditerpene and compound $\mathrm{C}_{2}$ (Molecular Mass: 418, $\left.\mathrm{C}_{24} \mathrm{H}_{34} \mathrm{O}_{6}\right)$ is $(12,13)$ - seco 12, 14 - epoxy, 12(16) -Oxo -,13(15), 16(17) - diene, 4, 10, 17 - trimethyl, 4, 7 - di - aceto cassanoate. Similar Cassane - type diterpenoids have been reported for promising antimicrobial properties.

Keywords: Calliandra portoricensis (Fabaceae), antibacterial, antifungal, cassane-type diterpenoid derivatives.

Copyright () 2020 The Author(s): This is an open-access article distributed under the terms of the Creative Commons Attribution 4.0 International License (CC BY-NC 4.0) which permits unrestricted use, distribution, and reproduction in any medium for non-commercial use provided the original author and source are credited.

\section{INTRODUCTION}

Over the years, humans have depended on natural products for basic needs such as food and medicines. Evidence abounds on how the ancient civilizations of Chinese, Indians and North Africans used plants for the treatment of various diseases [1].

There has been huge burden of the infectious diseases on the populace due to the newly emerging and re-emergent diseases as well as multiple drug- resistant microbial strains that have necessitated search for newer and better antimicrobial agents [2]. About $80 \%$ of world inhabitants patronize herbal medicine [3], and this is most pronounced in the resource - limited countries of the globe [4].

Currently, plants are still rated as the most economical and effective alternative source of medicines and 'lead' for novel drug discovery $[5,6]$. Studies are therefore needed to validate scientifically, the safety, efficacy, quality and dosage of medicinal plant used [7].

The plant Calliandra portoricensisis is a shrub distributed in tropical regions of America, India, West Indies and West African Nigeria [8]. Phytochemical constituents include; saponins, flavonoids, cardiac glycosides, steroids, triterpenoids, reducing compounds and alkalids [9]. 


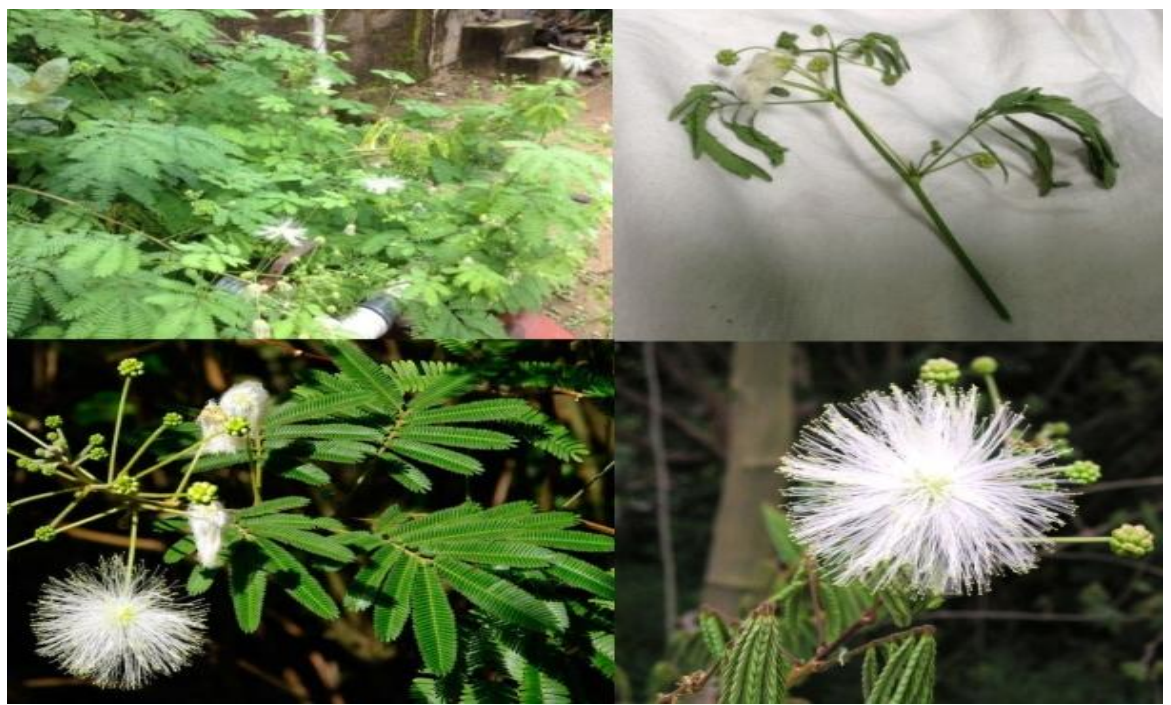

Fig-1: Photograph of Calliandra portoricensis showing, twigs, leaves and flowers

Ethnobotanically, the common names of Calliandra portoricensis include, "Sleeping plant" and "Corpse awakener," Tude (Yoruba of South Western Nigeria); [10]; "Ekweanahi" and "Avuvuagu" or "Eriagbo" among the Igbos of South Eastern Nigeria. In these regions, the plant has been used extensively in traditional medicine for the treatment of various ailments such as; throat and tooth inflammations, swollen tonsil, mouth ulcers. These medical conditions are usually caused by bacteria and fungi [11].
There were some previous scientific reports in the following domains; worm expeller, laxative, abortificient, antidote to viparean venon [12, 13]. Antidiarrhoea, anticonvulsant and antipyretic properties [14-16]. Also crude extracts of C. portoricensis, exhibited antimicrobial activity [17]. Antioxidant, antiangiogenic, and antiproliferative activities in human prostate cancer cells [18]. Antisickling properties [19]. Antioxidant and antihepatotoxic [20].

Table-1: Some chemical constituents previously isolated from the genus Calliandra

\begin{tabular}{|c|c|c|c|}
\hline Structural formular & $\begin{array}{l}\text { Name of Isolated } \\
\text { compound }\end{array}$ & Morphological part & References \\
\hline 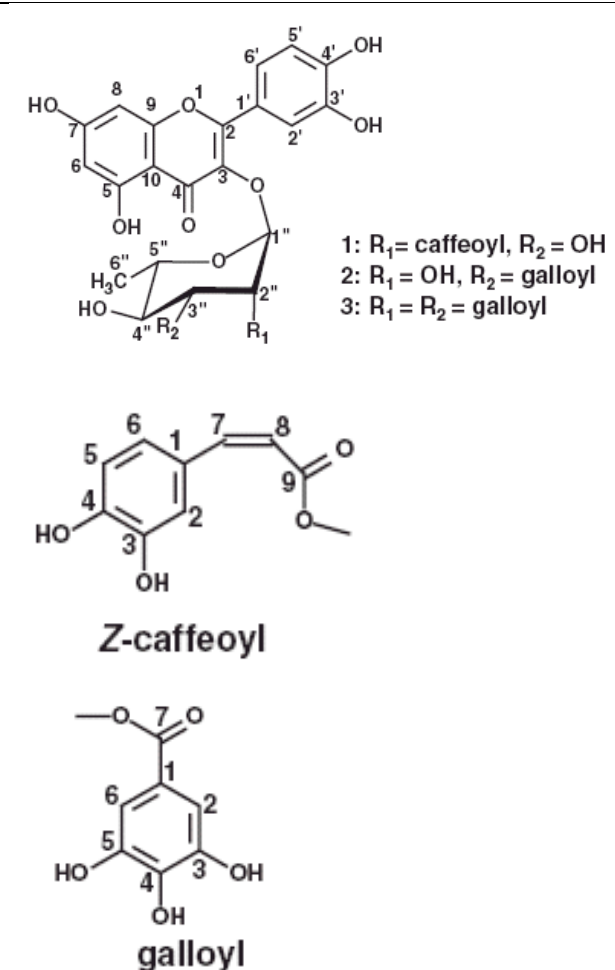 & $\begin{array}{l}\text { Quercitrin 2"-O-caffeate } \\
\text { Quercitrin 3"-O-gallate } \\
\begin{array}{l}\text { Quercitrin } 2 ", 3 " \text {-di-O- } \\
\text { gallate }\end{array}\end{array}$ & $\begin{array}{l}\text { Leaves and stem of } \\
\text { Calliandrahaematocephala }\end{array}$ & [21]; ) \\
\hline
\end{tabular}


Oguegbulu NE et al., Saudi J Med Pharm Sci, Dec, 2020; 6(12): 717-723

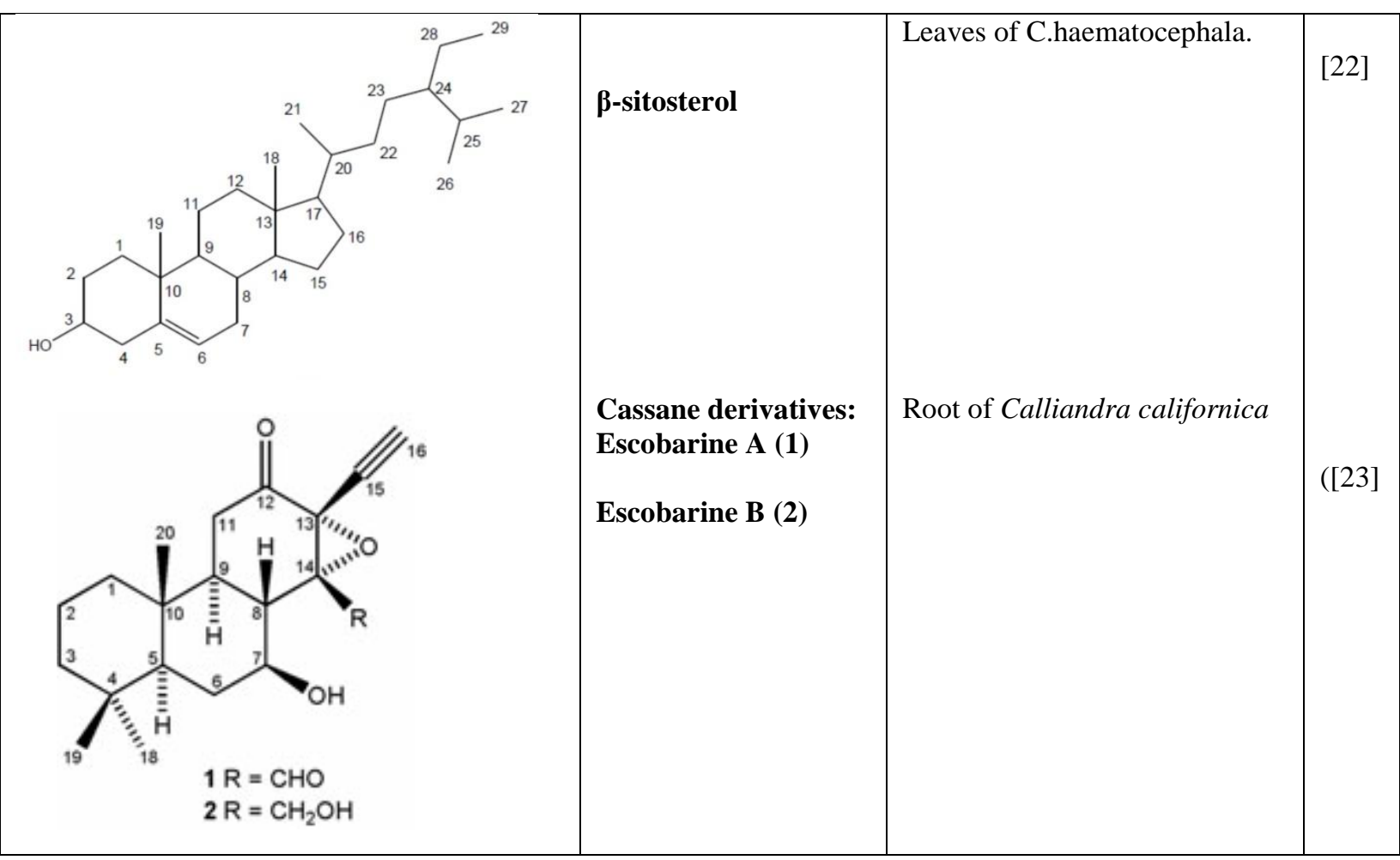

\section{Aims and objective of the study}

To identify, isolate and characterize the antimicrobial compounds from the root of C. portoricensis.

\section{MATERIALS AND METHODS \\ Plant Material}

The root sample of Calliandra portoricensis was collected in the month of June from Osisioma Local Government Area in Abia State of Nigeria. The plant was identified and authenticated in the Herbarium of the Department of Plant Science and Biotechnology, University of Port Harcourt, Rivers State, Nigeria by Dr. Chimezie Ekeke with the Voucher Number: UPH / V / 1240. The material was properly washed, air dried, pulverized and stored for subsequent use.

The methodology adopted the techniques as described earlier [24], for; extraction by successive cold maceration using n-hexane, ethyl acetate and $70 \%$ aq. Methanol for $72 \mathrm{hr}$ respectively, Anti-microbial in vitro susceptibility evaluation and Minimum Inhibitory Concentration (MIC) determinations by agar well diffusion method, preparation of test microorganisms which were; Staphylococcus aureus (Gram +ve cocci), Streptococcus fecalis (Gram +ve cocci), Escherichia coli (Gram -ve rod), Bacillus subtitlis (Gram +ve rod), Klebsiella pneumoneae (Gram -ve rod), Candida albican (fungi), Aspergillus niger (fungi), Also conducted was column Fractionation of bioactive ethyl acetate extracts (Silica Gel G, 200-400 mesh-stationary phase) with gradient mixtures of n-hexane: ethyl acetate: methanol (4:0:0; 3:1:0; 2:2:0; 1:3:0; 0:1:0; $0: 3: 1 ; 0: 2: 2 ; 0: 1: 3 ; 0: 0: 4 ;-\mathrm{v} / \mathrm{v} / \mathrm{v})$ used for the elution, The bioactive fraction (B) was subjected to further purification by preparative TLC, (Silica Gel G, $0.5 \mathrm{~mm}$ thickness), The resultant bioactive pure compounds $C_{1}$ and $\mathrm{C}_{2}$ were subjected to spectroscopic analysis (UV, MS, FT - IR and NMR).

\section{RESULTS AND DISCUSSION}

Table-2: Result of antimicrobial susceptibility tests of TLC bands $\left(C_{1}\right.$ and $\left.C_{2}\right)$ on selected human pathogens at concentration of $1 \mathrm{mg} / \mathrm{ml}$

\begin{tabular}{|c|c|c|c|c|}
\hline & \multicolumn{2}{|c|}{ TLC Band $\left[\mathrm{C}_{1}\right]$} & \multicolumn{2}{|c|}{ TLC Band $\left[\mathrm{C}_{2}\right]$} \\
\hline Microorganism & $\mathrm{C}-1$ & CTR & $\mathrm{C}-2$ & CTR \\
\hline Staphylococcusaureus & $* 25.00 \pm 0.40$ & $23.00 \pm 0.70$ & $* 31.00 \pm 0.12$ & $24.00 \pm 0.70$ \\
\hline Escherichia. Coli & $* 35.00 \pm 0.60$ & $38.00 \pm 0.90$ & $* 20.00 \pm 0.60$ & $25.00 \pm 0.70$ \\
\hline Bacillus subtitis & $* 45.00 \pm 0.50$ & $40.00 \pm 0.80$ & $* 22.00 \pm 0.50$ & $35.00 \pm 0.40$ \\
\hline Klebsiella pneumonae Streptococcus. fecalis & $\begin{array}{l}* 35.00 \pm 0.70 \\
* 30.00 \pm 0.20\end{array}$ & $\begin{array}{l}30.00 \pm 0.60 \\
35.00 \pm 0.10\end{array}$ & $\begin{array}{l}* 18.00 \pm 0.40 \\
* 20.00 \pm 0.80\end{array}$ & $\begin{array}{l}30.00 \pm 0.80 \\
25.00 \pm 0.40\end{array}$ \\
\hline Candida albicans & $* 33.00 \pm 0.90$ & $35.00 \pm .00$ & $* 20.00 \pm 0.90$ & $25.00 \pm 0.70$ \\
\hline Aspergillus $n$. & $* 25.00 \pm 0.50$ & $14.00 \pm 0.80$ & $* 30.00 \pm 0.50$ & $45.00 \pm 0.60$ \\
\hline
\end{tabular}


Values are Diameter Zone of Inhibition ( $\mathrm{mm})$ and expressed as mean $\pm \mathrm{SEM} ; \mathrm{n}=3$; CTR. = Control Ciproflaxacin $(20 \mu \mathrm{g}$ per $\mathrm{ml}$ for bacteria) and Fluconazole $(1000 \mu \mathrm{g}$ per $\mathrm{ml}$ for fungi); $(-)=$ no inhibition; $10 \%$ aqueous DMSO (negative control, no inhibition).

* Represent the significant values with respect to the control at $\mathrm{P} \leq 0.05$.

Table-3: Minimum Inhibitory Concentrations (MIC) values of TLC bands $\left(C_{1}\right.$ and $\left.C_{2}\right)$ in $\mu \mathrm{g}$ per ml against the selected human pathogens

\begin{tabular}{|l|l|l|l|}
\hline \multirow{2}{*}{ S/N } & \multirow{2}{*}{ Micro organisms } & TLC Bands. \\
\cline { 3 - 4 } & & $\mathbf{C}_{\mathbf{1}}$ & $\mathbf{C}_{\mathbf{2}}$ \\
\hline 1. & Staphylococcus. Aureus & $125.00 \pm 0.80$ & $125.00 \pm 0.10$ \\
\hline 2. & Escherichia. Coli & $25000 \pm 0.30$ & $125.00 \pm 0.70$ \\
\hline 3. & Bacillus. Subtitis & $125.00 \pm 0.20$ & $250.00 \pm 0.30$ \\
\hline 4. & Klebsiella pneumoneae & $250.00 \pm 0.60$ & $125.00 \pm 0.80$ \\
\hline 5. & Streptococcus fecalis & $12500 . \pm 0.50$ & $125.00 \pm 0.10$ \\
\hline 6. & Candida albicans & $125.00 \pm 0.70$ & $125.00 \pm 0.40$ \\
\hline 7. & Aspergillus niger & $125.00 \pm 0.20 .5$ & $125.00 \pm 0.60$ \\
\hline
\end{tabular}

Values are expressed as mean $\pm \mathrm{SEM} ; \mathrm{n}=3$.

Table-4: Interpretation of ${ }^{1} \mathrm{H}$ and ${ }^{13} \mathrm{C}$ NMR Spectral data (Deuterated Chloroform_ $\mathrm{CDCl}_{3}$ as solvent) for compounds $\mathrm{C}_{1}$ and

\begin{tabular}{|c|c|c|c|c|c|c|c|c|c|c|}
\hline \multirow{3}{*}{$\begin{array}{l}\text { Assigned position/ } \\
\text { identity of atoms }\end{array}$} & \multirow{2}{*}{\multicolumn{2}{|c|}{$(\delta)-{ }^{13} \mathrm{C}(\mathrm{ppm})$}} & \multirow{2}{*}{\multicolumn{2}{|c|}{$\delta_{\mathrm{H}}(\mathbf{p p m})$}} & \multirow{2}{*}{\multicolumn{2}{|c|}{${ }^{1} \mathrm{H}-\mathrm{H}$ COSY }} & \multirow{2}{*}{\multicolumn{2}{|c|}{$\begin{array}{l}\mathbf{H M B C} \\
\mathbf{2 , 3 , 4} \mathbf{J}_{\mathrm{HC}}\end{array}$}} & \multirow{2}{*}{\multicolumn{2}{|c|}{ DEPT-135 }} \\
\hline & & & & & & & & & & \\
\hline & $\mathrm{C}_{1}$ & $\mathrm{C}_{2}$ & $\mathrm{C}_{1}$ & $\mathrm{C}_{2}$ & $\mathrm{C}_{1}$ & $\mathrm{C}_{2}$ & $\mathrm{C}_{1}$ & $\mathrm{C}_{2}$ & $\mathbf{C}_{1}$ & $\mathbf{C}_{2}$ \\
\hline $\mathrm{C}-1$ & 22.0 & 29.85 & -0.88 & $1.2-1.3$ & & & & & $\mathrm{CH}_{2}$ & $\mathrm{CH}_{2}$ \\
\hline $\mathrm{C}-2$ & 18.2 & 29.51 & $0.9,1.2$ & $1.2-1.3$ & & & & & $\mathrm{CH}_{2}$ & $\mathrm{CH}_{2}$ \\
\hline $\mathrm{C}-3$ & 22.8 & 33.97 & 1.32 & $1.2-1.3$ & & & & & $\mathrm{CH}_{2}$ & $\mathrm{CH}_{2}$ \\
\hline $\mathrm{C}-4$ & 45.8 & 54.66 & & - & & & & & & - \\
\hline $\mathrm{C}-5$ & 29.8 & 22.85 & 1.33 & 0.9 & & & & & $\mathrm{CH}_{2}$ & $\mathrm{CH}$ \\
\hline $\mathrm{C}-6$ & 21.1 & 33.39 & 1.3 & $1.2-1.3$ & & & & & $\mathrm{CH}_{2}$ & $\mathrm{CH}_{2}$ \\
\hline $\mathrm{C}-7$ & 21.7 & 44.49 & 0.9 & 3.7 & & $\mathrm{H}_{8}$ & & & $\mathrm{CH}_{2}$ & $\mathrm{CH}$ \\
\hline $\mathrm{C}-8$ & 25.0 & 41.85 & 1.68 & 3.3 & & $\mathrm{H}_{7}$ & & & $\mathrm{CH}_{2}$ & $\mathrm{CH}$ \\
\hline C-9 & 23.0 & 22.24 & 1.45 & 0.8 & & & & & $\mathrm{CH}_{2}$ & $\mathrm{CH}$ \\
\hline $\mathrm{C}-10$ & 38.0 & 52.96 & 2.4 & - & & & & & $\mathrm{CH}$ & - \\
\hline $\mathrm{C}-11$ & 30.2 & 32.08 & $1.4,1.75$ & 1.2 & H12 & & & & $\mathrm{CH}_{2}$ & $\mathrm{CH}_{2}$ \\
\hline $\mathrm{C}-12$ & 65.7 & 95.21 & 4.3 & 5.98 & H11 & & & & $\mathrm{CH}_{2} \mathrm{OR}$ & $\mathrm{OCHO}$ \\
\hline $\mathrm{C}-13$ & 127.9 & 111 & 7.6 & 5.40 & H15 & & & & $=\mathrm{CH}$ & $=\mathrm{CH}$ \\
\hline $\mathrm{C}-14$ & 28.7 & 82 & 2.04 & 3.60 & & & & $\mathrm{C}_{21}$ & $\mathrm{CH}$ & $\mathrm{OCH}$ \\
\hline $\mathrm{C}-15$ & 129.9 & 109 & 7.4 & 6.05 & $\mathrm{H} 13$ & & & & $=\mathrm{CH}$ & $=\mathrm{CH}$ \\
\hline C-16 & $170 \mathrm{ca}$ & 140 & - & - & & & & & $\mathrm{RO}-\mathrm{C}=\mathrm{O}$ & - \\
\hline $\mathrm{C}-17$ & 13.1 & 95.09 & 0.99 & 6.04 & & & & & $\mathrm{CH}_{3}$ & $=\mathrm{CH}$ \\
\hline $\mathrm{C}-18$ & 11 & 14.23 & 0.95 & 0.95 & & & & & $\mathrm{CH}_{3}$ & $\mathrm{CH}_{3}$ \\
\hline C-19 & 14 & 14.53 & 0.9 & 0.75 & & & $\begin{array}{l}\mathrm{C} 2, \\
\mathrm{C} 4\end{array}$ & & $\mathrm{CH}_{3}$ & $\mathrm{CH}_{3}$ \\
\hline $\mathrm{C}-20$ & 67.2 & 170 & 4.23 & - & & & & & $\mathrm{CH}_{2} \mathrm{OH}$ & $\mathrm{R}-\mathrm{O}-\mathrm{C}=\mathrm{O}$ \\
\hline $\mathrm{C}-21$ & & 164 & & - & & & & & & $\mathrm{R}-\mathrm{O}-\mathrm{C}=\mathrm{O}$ \\
\hline C-22 & & 18.81 & & 1.0 & & & & & & $\mathrm{CH}_{3}$ \\
\hline $\mathrm{C}-23$ & & 56.71 & & 3.80 & & & & $\mathrm{C}_{20}$ & & $\mathrm{OCH}_{3}$ \\
\hline C-24 & & 55.89 & & 3.70 & & & & $\mathrm{C}_{21}$ & & $\mathrm{OCH}_{3}$ \\
\hline
\end{tabular}

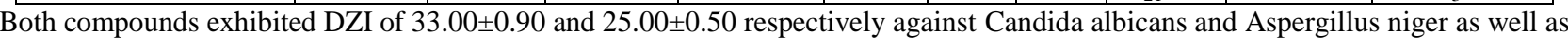
MIC values of $125.00 \pm 0.70 \mu \mathrm{g}$ per $\mathrm{ml}$ for each. These activities were found to be quite significant with respect to the reference controls (Ciprofloxacin and fluconazole) at $\mathrm{P}<0.05$.

The susceptibility tests result shown in (Table 1) was found to be consistent with the report which suggested that Diameter Zone of Inhibition of $10 \mathrm{~mm}$ and above despite the current ease of acquired microbial resistance should be considered to possess some antimicrobial activity; while those equal to or above $20 \mathrm{~mm}$ could be considered potent [25].. Further, the result shown on (Table 2), on MIC values was in line with report of an investigation which expressed that extracts having activity where MIC values were below $8 \mathrm{mg} / \mathrm{ml}$ were considered to possess some antimicrobial activity, whereas natural products with MIC values below $1 \mathrm{mg} / \mathrm{ml}$ should be considered as noteworthy [26].

Compound $\mathrm{C}_{1}$ had an $\mathrm{R}_{\mathrm{f}}$ value of 0.72 (Silica Gel, $0.25 \mathrm{~mm}$, n-hexane: ethyl acetate: methanol - 12: 4: 1) and fluoresced light green under the UV lamp at 
$365 \mathrm{~nm} . \mathrm{C}_{1}$ was a semi solid, oily and dark brown compound. The Ultra Violet (UV) spectrum, exhibited absorption maximum at $280 \mathrm{~nm}$. This was consistent with values reported on Cassane - type tricyclic diterpenoids [27], and supported by the presence of conjugated chromophoric group on ring $\mathrm{C}$ of compound $\mathrm{C}_{1}$. The structure of this compound was elucidated by using FT - IR, NMR (1- D and 2 - D experiments) and MS spectroscopic data., The IR bands were in the region; $3402.54 \mathrm{~cm}^{-1}$ and $2959.47 \mathrm{~cm}^{-1}$, representing the $-\mathrm{OH}$ stretching and $-\mathrm{CH}$ vibrations respectively. Also evident were the carbonyl stretch at $1727.30 \mathrm{~cm}^{-1}$, $\alpha$ and $\beta$, unsaturation at $1415.52 \mathrm{~cm}^{-1}$

The proton $\left({ }^{1} \mathrm{H}\right)-$ NMR contained five peaks of deshielded protons at $\delta_{\mathrm{H}}(\mathrm{ppm}) ; 7.6,7.4,4.26,4.25$ and 2.04 .

The cosy spectrum revealed the correlation of the proton peaks and exhibited cross - peak corrilatins as in; proton $\mathrm{H}-12$ with $\mathrm{H}-11$ and $\mathrm{H}-13$ with $\mathrm{H}-$ 15. Three methyl protons singlets were evident at $\delta_{\mathrm{H}}$ : (ppm); $\mathrm{H}-17-\mathrm{Me}(0.99) ; \mathrm{H}-18-\mathrm{Me}(0.95)$ and $\mathrm{H}-$ 19 - Me (0.90). Evident too were nine methylene $\left(\mathrm{CH}_{2}\right)$ protons corresponding to $\mathrm{H}-1, \mathrm{H}-2, \mathrm{H}-3, \mathrm{H}-$ $5, \mathrm{H}-6, \mathrm{H}-7, \mathrm{H}-8, \mathrm{H}-9$ and $\mathrm{H}-11$ respectively. Also present were four methine $(\mathrm{CH})$ protons at; $\mathrm{H}-10$ and $\mathrm{H}-14$ respectively. The olefinic $\left(\mathrm{Sp}^{2}\right)=\mathrm{CH}-$ protons were evident at $\mathrm{H}-13$ and $\mathrm{H}-15$. The methoxy $\left(-\mathrm{OCH}_{2}-\right)$ proton at $\mathrm{H}-12$ was evident too. Also present were secondary alcohol protons $\left(-\mathrm{CH}_{2}\right.$ $\mathrm{OH})$ at $\mathrm{H}-20$. The clear designations and identity of atoms was achieved by use of 2 - Dimensional proton to carbon correlation (HMBC and HSQC). The other proton chemical shift peaks were equally rationalized on Table 4.

A total of twenty spectral peaks were identified in ${ }^{13} \mathrm{C}$ - NMR experiment of compound $\mathrm{C}_{1}$. These were rationalized by the aid of DEPT -135 . Three methyl groups at $\delta \mathrm{c}(\mathrm{ppm}) ; 13.10,11.00$ and 14.00 corresponding to $\mathrm{C} 17-\mathrm{Me}, \mathrm{C} 18-\mathrm{Me}$ and $\mathrm{C} 19-$ Me respectively. Olefinic group $(\mathrm{C}=\mathrm{C})$ at $\delta \mathrm{c}(\mathrm{ppm})$ : $127.90(\mathrm{C}-13$ and $129.90(\mathrm{C}-15)$ respectively. Nine methylene $\left(-\mathrm{CH}_{2}\right)$ groups at $\delta \mathrm{c}(\mathrm{ppm}) ; 22.00(\mathrm{C}-1)$, $18.20(\mathrm{C}-2) 22.80$ (C - 3), 29.80 (C -5), 21.10 (C -6), 25.00, (C - 7) 21.70, (C -8), 23.00 (C-9) and 30.20 (C11). One dioxymethylene groups $\left(\mathrm{O}-\mathrm{CH}_{2} \mathrm{O}\right)$ at; 65.70 (C-12) was evident. Present also were two methine groups (-CH-) at; $38.00(\mathrm{C}-10)$ and $28.70(\mathrm{C}-14)$ respectively. Evident also were two querternary groups at; $45.80(\mathrm{C}-4)$ and $170.00(\mathrm{C}-16)$ respectively.

Other correlations were evident in HMBC as rationalized in Table 4. The number assignment of hydrogen, carbon and oxygen was further supported by the MS spectrum The Mass and NMR (1D AND 2D) spectral data suggested the presence of Cassane - type tricyclic diterpenoid. This skeleton is usually linked to certain sub group in Fabaceae family [28]. Again, a peak was shown at $\mathrm{m} / \mathrm{z} 325$ and corresponded to $[\mathrm{M}+$ 1] equivalent to molecular mass of $324\left(\mathrm{C}_{20} \mathrm{H}_{36} \mathrm{O}_{3}\right)$.

Compound $\mathrm{C}_{1}$ is therefore a Cassane - type tricyclic diterpenoid derivative with (IUPAC) name as; (5, 10- 8,9- 12,13)-seco_4,4,10 - trimethyl, 14 hydroxymethyl, 16 - keto, 13(15) - ene - cassane furanoditerpene (Figure 2).

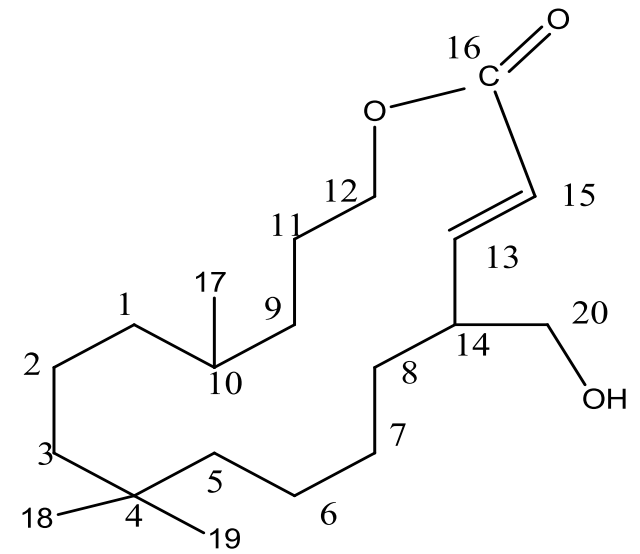

Fig-2: The structure of compound $C_{1} \cdot(5,10-8,9-12,13)$ Seco-4, 4, 10 - trimethyl, 14 -

hydroxymethyl, 16 - keto, 13(15) - ene - cassane furanoditerpene

Compound $\mathrm{C}_{2}$ had an $\mathrm{R}_{\mathrm{f}}$ value of 0.59 on analytical TLC plate (Silica Gel, $0.25 \mathrm{~mm}$, n-hexane: ethyl acetate: methanol - 12: 4: 1) and fluoresced deep purple under a UV lamp at $365 \mathrm{~nm}$. It was also a semisolid and oily compound with molecular formular of $\mathrm{C}_{24} \mathrm{H}_{34} \mathrm{O}_{6}$ as could be deduced from the MS spectral data by a peak showing at $\mathrm{m} / \mathrm{z} 419$ corresponding to $[\mathrm{M}+1]$ equivalent to its molecular mass of 418 .

The FT-IR of $\mathrm{C}_{2}$ showed an carbomyl $(\mathrm{C}=0)$ stretching in the band region of $1710.33 \mathrm{~cm}^{-1}$. Presence of $-\mathrm{CH}, \mathrm{CH}_{2}, \mathrm{CH}_{3}$ vibrational frequencies were also evident.

The ${ }^{1} \mathrm{H}-\mathrm{NMR}$ for compound $\mathrm{C}_{2}$ exhibited signals of eight deshielded protons with chemical shifts at $\delta_{\mathrm{H}}(\mathrm{ppm}) 6.05,6.04,5.98,5.40,3.80,3,70,3.60$ and 3.30 , corresponding to; H-15, H-17, H-12, H-13, H-23, $\mathrm{H}-7 / 24, \mathrm{H}-14$ and $\mathrm{H}-8$ respectively. Five quaternary carbons with no protons at; C-4, C-10, C- 16, C - 20, and $\mathrm{C}-21$, were evident.Also evident were the three methy protons singlets at chemical shifts $\delta_{\mathrm{H}}(\mathrm{ppm})$; $0.95,0.75$ and 1.0 , corresponding to; C-10-Me, C-4$\mathrm{Me}$, and $\mathrm{C}-17-\mathrm{Me}$ respectively. Olefinic $\left(\mathrm{Sp}^{2}\right)$ protons at $\delta_{\mathrm{H}}(\mathrm{ppm}) ; \mathrm{H}-13(5.40), \mathrm{H}-15$ (6.05) and $\mathrm{H}-17$ (6.04). Present too were the oxymethine protons at $\delta_{\mathrm{H}}$ (ppm); H-12 (5.98) and H-14 (3.60) respectively.

The structural configuration of this compound $\mathrm{C}_{2}$ was further supported by a total of twenty four carbon signals in ${ }^{13} \mathrm{C}-\mathrm{NMR}$ spectroscopy. These resonances were rationalized on the basis of DEPT- 
135. (Table 4). Five quaternary carbons at $\delta \mathrm{c}(\mathrm{ppm})$; C4 (54.66), C-10 (52.96), C - 16 (140.0), C-20 (170.0) and $\mathrm{C}-21$ (164.0). Three methy group carbons were evident at $\delta \mathrm{c}(\mathrm{ppm})$ : Me - C-18 (14.23), Me - C-19 (14.53), and $\mathrm{Me}-\mathrm{C}-22$ (18.81). Five methylene groups $\left(-\mathrm{CH}_{2}\right.$ ) at $\delta \mathrm{c}$ (ppm) C-1 (29.85), C-2 (29.51), C-3 (33.97), C-6 (33.39) and C-11 (32.08). Present too were the two oxymethine groups $(>\mathrm{CHO})$ at $\delta \mathrm{c}(\mathrm{ppm}): \mathrm{C}-12$ (95.21) and C-14 (82.00). Four olefinic methine carbon atoms were evident at $\delta \mathrm{c}(\mathrm{ppm}) ; \mathrm{C}-13$ (111.00), C-15 (109.00) and C-17 (95.09).

The ${ }^{1} \mathrm{H}-\mathrm{H}$ COSY spectral data indicated that proton $\mathrm{H}-8\left(\delta_{\mathrm{H}}=3.30 \mathrm{ppm}\right) \quad$ exhibited cross - peak correlation with $\mathrm{H}-7\left(\delta_{\mathrm{H}}=3.70 \mathrm{ppm}\right)$. At the same time, the following correlations were observed with $\mathrm{HMBC}$ spectrum; proton $\mathrm{H}-14\left(\delta_{\mathrm{H}}=3.60 \mathrm{ppm}\right) \quad$ with $\mathrm{C}$ $21\left(\delta_{\mathrm{C}}=164.00 \mathrm{ppm}\right), \mathrm{H}-23\left(\delta_{\mathrm{H}}=3.80 \mathrm{ppm}\right)$ with $\mathrm{C}-$ $20\left(\delta_{\mathrm{C}}=170.00 \mathrm{ppm}\right)$ and $\mathrm{H}-24\left(\delta_{\mathrm{H}}=3.70 \mathrm{ppm}\right)$ with $\mathrm{C}-21\left(\delta_{\mathrm{C}}=164.00 \mathrm{ppm}\right)$.

The absorption maximum in UV- VIS experiment was at $270 \mathrm{~nm}$. This is consistent with earlier report on Cassane skeleton. This novel compound $\mathrm{C}_{2}$ isolated from the root of Calliandra portoricensis was identified as $(12,13)$ - seco - 12, 14 epoxy, 12(16) -Oxo -, 13(15), 16(17) - diene, 4, 10, 17 - trimethyl, 4, 7 - di - aceto cassanoate (Figure 3).

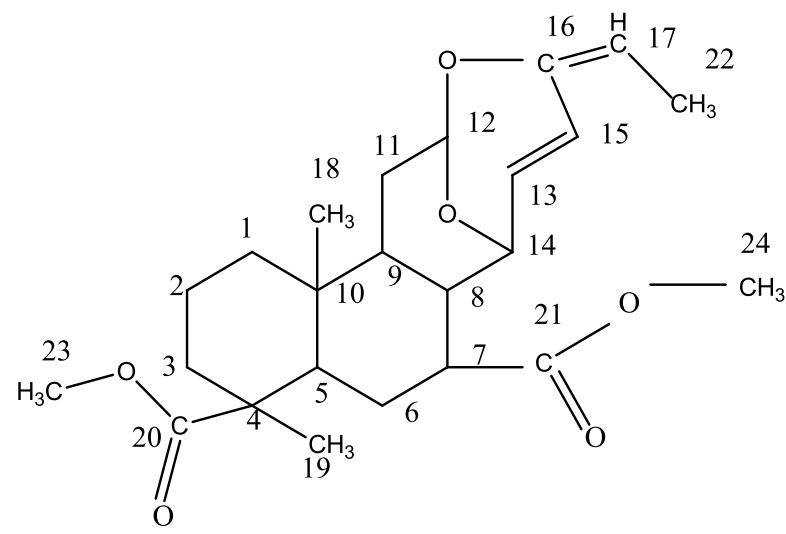

Fig-3: The structure of compound $\mathrm{C}_{2}:(12,13)$ - seco - 12, 14 - epoxy, 12(16) -Oxo-, 13(15), 16(17) - diene, 4, 10, 17 trimethyl, 4, 7 - di - aceto cassanoat.

The two compounds $\mathrm{C}_{1}$ and $\mathrm{C}_{2}$ being Cassane - type diterpenoid derivatives, could be linked to earlier reported activities exhibited by similar moieties against test bacteria, virus and candida albican - fungus [23, 29, 30]

\section{CONCLUSION}

This study had successfully isolated, identified and characterized two novel Cassane - type tricyclic diterpenoid derivatives. Compound $\mathrm{C}_{1}$ as; $(5,10-8,9$ 12,13)-seco_ 4,4,10 - trimethyl, 14 - hydroxymethyl, 16 - keto, 13(15) - ene - cassane furanoditerpene. (Molecular mass: 324 and molecular formular: $\mathrm{C}_{20} \mathrm{H}_{36}$ $\mathrm{O}_{3}$ ). and Compound $\mathrm{C}_{2}$ as; $(12,13)$ - seco - 12, 14 - epoxy, 12(16) -Oxo -,13(15), 16(17) - diene, 4, 10, 17 - trimethyl, 4, 7 - di - aceto cassanoate (Molecular mass: 418 and molecular formular: $\mathrm{C}_{24} \mathrm{H}_{34} \mathrm{O}_{6}$ ). These Cassane - type diterpenoids have shown promising activities against human pathogenic bacteria and fungi (Candida albican).

\section{ACKNOWLEDGEMENT}

Staff members and Laboratory facilities of Pharmacognosy \& Phytotherapy and Pharmaceutical \& Medicinal Chemistry Departments both of Faculty of Pharmaceutical Sciences, University of Port Harcourt, Rivers State,Nigeria. Also, the Central Laboratory of Kwame Nkuruma University of Science and Technology, Kumasi Ghana for hosting me and undertaking the laboratory high-Tech spectroscopic analysis of all my samples

\section{CONFLICT OF INTEREST}

There was no conflict of interest involved in this research work.

\section{REFERENCES}

1. Phillipson, J.D. (2001). Phytochemistry and Medicinal plants.Phyto chemistry 56, 237 - 243.

2. Yoneyama, I.J., Katsumala, R. (2006). Antibiotic Resistance in bacteria and its future for novel antibiotic development. Bio Science, Biotechnology and Biochemistry, 70(5); 10601075.

3. WHO. (1985). Bulletin of the World Health Organization, 63(6); $965-981$.

4. Farnsworth, N.R. (1994). The Role of Medicinal Plants in drug development. In; KrogsgaardLarsen, S., Brogger - Christensen, S., Kofod, H. (Eds). Natural Products and Drug Development Munksgaard, Copenhagen.

5. Vander, Watt, E., Pretorius, J.C. (2001). Purification and identification of active components of CarpobiotusedulislL. Journal of Ethno Pharmacology, 7687-91.

6. Cos, P., Vlietinck, A.J., Berghe, D.V. (2006). Antiinfective potential of Natural Products: How to develop a stronger in vitro 'Proof - of concept'. Journal of Ethnopharmacology, 106, 290 - 302.

7. Maska, P.J., Afolayan, A.J. (2002). Anti-microbial activity of some plants used for the treatment of livestock disease in the Eastern cape South Africa. Journal of Ethnopharmacology, 83, 129 - 134.

8. Burkill, H.M. (1985). The useful plants of West Tropical Africa. Families, Royal Botanic Gardens. Kew. Great Britain, 3; 177 - 266.

9. Oguegbulu1, E.N., Abo, A.K., Afieroho, O. E. (2020). Comparative Evaluation of the Antimicrobial Activities of some plants used in Natural Medicine -Spondiasmombin, Calliaidra portoricensiss, Dennettia tripetala, Anthocleista djalonensis and Cronton zambesicus. Saudi Journal of Pathology and Microbiology, 5(5): 257-262. 
10. Fatokun, O.T., Wojuola, T.E., Esievo, K.B. Kunle, O.F. (2006). Medicinal Plants used in the Management of Asthma; A Review. European Journal of Pharmaceutical and Medicinal Research, 3(7):82-92.

11. Holist, N.O. (2004). A collection of Traditional Yoruba oral and Dental Medicaments. Book Builders. Ibadan, Nigeria 123.

12. Onyeama, H.P., Ebong, P.E. Eteng, M.U., Igile, G.O., Ibekwe, H.A., Ofemile, P.Y. (2012). Histopathological responses of the Heart, Lines and kidney to Calliandria portoricensis Extracts in Wisbor Rats challenged with venom of Echisocellatus. Journal of App. Pharma. Sciences, 02(06): $164-171$.

13. Ayensu, E.S. (1972). Medicinal plants of West Africa References, publications, Inc. Algonac Michigan USA.

14. Aguwa, C.N., Lawal, A.M. (1988). Pharmacological studies on the active principle of Calliandra portoricensis leaf extracts Journal of Ethnopharmacology, 22:63 - 71.

15. Akah, A.P., Nwiwu, I.J. (1988). Anti convulsant activity of the root and stem of Calliandriaportoricesis. Journal of Ethnopharmcology, 22, 205 - 210.

16. Orishadipe, A.T., Okogun, J.I., Mishelia, L. (2010). Gas chromatography - mass spectrometry analysis of the hexane extract of Calliandria portoricensis and its antimicrobial activity. African Journal of Pure and Applied Chemistry, 4(7): 131 - 134.

17. Oguegbulu, E.N, Abo, A.K, Afieroho, O.E. (2020). Comparative Evaluation of the Antimicrobial Activities of some plants used in Natural Medicine-Spondiasmombin, Calliaidra portoricensiss, Dennettia tripetala, Anthocleista djalonensis and Cronton zambesicus. Saudi Journal of Pathology and Microbiology, 5(5): 257-262.

18. Adaramoye, O., Erguen, B., Oyebode, O., Nitzsche, B, Hopfner, M., Juna, K., Rabien, A. (2015). Antioxidant, antiangiogenic and antiproliferation activities of root methanol extract of Calliandra portoricensis in human prostate cancer cells. Journal of Integrative Medicine, 18(3): 185-93.

19. Amujoyegbe, O.O., Agbedahunsi, J.M., Akanmu, M.A. (2014). Antisickling properties of two Calliandria species C. portoricensis and C. haematocephala (Fabaceae). European Journal of Medicinal Plants, 4(2); 206 - 219.
20. Amr, M., Abo-Elhamd, Ahmed, M. Aboul-Enein, Samy, M, Mohamed Ahmed, S., Shalaby, Usama. Konsowa, U, Hassan E.M., Metwally, N.S. (2016). Chemical Characterization, antioxidant and antihepatotoxic activities of Calliandrahaematocephala (Hassk), vgrowing in Egypt. Journal of Chemical and Pharmaceutical Research, 8(4): 828-845.

21. Moharram, F.A., Marzouk, M.S., Ibrahim, MT., Mabry, T.J. (2006). Antioxidant galloylated flavonol glycosides from Calliandrahaematocephela. Journal of Natural Product Research, 20(16):927-34.

22. El-Sayed, M. E. (2014). Phytoconstituents from Calliandrahaematocephala and their biological activities. Journal of Pharmaceutical Sciences, 49: 259-268.

23. Encarnacion-Dimayuga, R., Agundez-Espinoza, J., Gorcia, A., Delgado, G., Molina-Salinas, G. (2006). Two New Cassane-Type Diterpenes from Calliandra californica. Letter. Planta Medica. 72: $757-761$.

24. Oguegbulu, E.N, Abo, A.K. (2020). Chromatographic Isolation of Antimicrobial Compounds ofCalliandraportoricensis (Jacq)-Benth (Fabaceae) Root. Middle-East Journal of Scientific Research, 28(3): 225-234.

25. Anyanwu, M.U., Okoye, R.C. (2017). Antimicrobial activity of Nigerian Medicinal Plants. Journal of Intercultural Ethnopharmocology, 6(2); $240-259$.

26. Bios, J.L., Recio, M.C. (2005). Medicinal Plants and Antimicrobial. Journal of Ethnopharmacology, 100; 80-84.

27. Berania, B.C., Djalma, M.O., Ezequias, P.S., Elaine, M.S., Adriano, M.C., Santos, D.M, Rabelo, A, Zani, C.L. (2011). New cassane diterpenes from Caesalpina echinate. Fitoterapia, 82(7):969 -975.

28. Barba, B., Dias, J.G., Goedken, V.L., Herz, W., Dominguez, X.A. (1992). Unusual Cassanes from Chamaecrista species. Tetrahedron, 48; 4725 4732.

29. Jiang, R, Ma, S.C, But, P.P.H. (2001). Antiviral cassane furanditerpenes from Caesalpinia minax, Journal of Natural Products, 64(10): $200-217$

30. Favre - Godal, G., Dorsaz, S., Queiraz, E.F., Marcourt, L., Ebrahim, S.N., Allard, P., Voinesco, F., Hamburger, M., Gupta, M.P., Gindro, K., Sanglad, D., Wolfender, T. (2015). Anti - Candida Cassane - Type Diterpenoids from the Root Bark of Swartzia simplex. Journal of Natural Products, 78(12): 2994 - 3604. 